\title{
EVALUASI SIFAT REPRODUKSI DAN SIFAT GELONDONGAN GENERASI PERTAMA EMPAT STRAIN IKAN BAUNG (Mystus nemurus) DI KERAMBA JARING APUNG
}

\author{
Atmadja Hardjamulia') dan Ningrum Suhenda
}

\begin{abstract}
ABSTRAK
Ikan baung merupakan jenis ikan perairan umum yang mempunyai nilai ekonomi yang relatif tinggi dan mempunyai potensi untuk dikembangkan sebagai ikan budi daya. Namun demikian penguasaan teknologi budi dayanya, khususnya pembenihan, belum berkembang di masyarakat. Upaya perlu dilakukan dalam rangka mendapatkan strain ikan baung yang efisien untuk dikembangkan. Penelitian ini dilakukan di Waduk Cirata, bertujuan untuk mengevaluasi sifat reproduksi empat strain ikan baung yang berasal dari Waduk Cirata dan Jatiluhur (di Jawa Barat). Wadaslintang, dan Wonogiri (di Jawa Tengah) serta sifat gelondongan yang dihasilkannya. Indukinduk dengan bobot bervariasi antara 185-1320 g/ekor dipelihara di keramba jaring apung (KJA) berukuran $3 \times 3 \times 2,5 \mathrm{~m}^{3}$ menggunakan kepadatan 18 ekor. Pakan yang diberikan berupa pelet dengan kandungan protein $30 \%$, dan ransum harian 3\% bobot badan. Data kematangan gonad, pemijahan, indeks ovisomatik(IOS), fekunditas, dan telur dianalisis secara deskriptif. Gelondongan dipelihara di KJA ukuran $1 \times 1 \times 2,5 \mathrm{~m}^{3}$ menggunakan kepadatan 50 ekor dengan rataan bobot awal 25,8 g/ekor. Pakan yang diberikan berupa pelet berkadar protein $30 \%$ dengan ransum harian $4 \%$ bobot badan/hari. Rancangan yang dipergunakan rancangan acak lengkap dengan tiga perlakuan (strain Cirata, Jatiluhur, dan Wonogiri) dan tiga ulangan. Hasil penelitian menunjukkan bahwa keempat strain ikan baung dapat matang gonad di keramba jaring apung (KJA) dan dapat dibiakkan dengan keberhasilan 92\%. IOS berkisar antara 3,56\%-13,71\% dengan kecenderungan strain Cirata dan Wonogiri yang terbesar. Fekunditas bervariasi antara 18 730-72 160 butir/kg induk dengan kecenderungan strain Cirata dan Wonogiri yang terbesar. Gelondongan strain Jatiluhur telah menunjukkan laju pertumbuhan spesifik, retensi protein dan konversi pakan yang lebih baik daripada strain-strain lainnya.
\end{abstract}

ABSTRACT: Evaluation of reproductive traits and characteristics of the first generation of green catfish (Mystus nemurus) fingerlings reared in floating net cages. By: Atmadja Hardjamulia and Ningrum Suhenda

Green catfish is an economical openwaters species, which has a potential development as a cultured species. So far, seed production technology of the species has not been developed. Effort has been made to obtain better strain of green catfish. The objective of the research was to evaluate the reproductive traits and characteristics of four strain green catfish fingerlings originally from Cirata and Jatiluhur (both in West Java), as well as Wadaslintang and Kedungombo (both in Central Java) reservoirs. The experiment was conducted in floating nets in Cirata reservoir. Broodstock with an individual weight varied of 185-1,320 g were reared in floating net cages of $3 \times 3 \times 2.5 \mathrm{~m}^{3}$ with a stocking density of $18 \mathrm{fish} / \mathrm{cage}$. Pelleted feed with $30 \%$ protein content was given with a daily ration of $3 \%$ of body weight. Gonad maturity, artificial propagation, ovisomatic index (OSI), fecundity, and egg size were observed. Fisrt generation of fingerlings with average an intitial weight of $25.8 \mathrm{~g}$, were reared in cages of $1 \times 1 \times 2.5 \mathrm{~m}^{3}$ with a stocking density of 50 fish/cage (except for Wadaslintang strain was 18 fish/cage). Pelleted feed (30\% protein) was used with a daily ration of $4 \%$ of body weight, three times a day. Randomized experimental design was applied for three strains (Cirata, Jatiluhur, and Wonogiri) with three replicates. Parameters of the experiment were specific growth rate, survival rate, protein and fat retention. The result revealed that the fish were able to mature in floating net cages and succesfully propagated with a average rate of $92 \%$. OSI varied from 3.56-13.71\%, with a trend of Cirata and Wonogiri strain larger than the other strains. Fecundity varied from 18730 to 72160 eggs/kg of body weight. Fingerling of Jatiluhur strain showed better growth rate, protein and fat retention than the other strains.

KEYWORDS : green catfish, reproductive traits, fingerling characteristics, ovisomatic index, protein retention, fat retention

Peneliti pada Balai Penelitian Perikanan Air Tawar 


\section{PENDAHULUAN}

Ikan baung (Mystus nemurus) dengan sinonim Macrones nemurus tergolong jenis-jenis lele (catfish) yang merupakan anggota dari Famili Bagridae, Ordo Siluriformes (Kottelat et al., 1993). Nama daerah ikan baung antara lain tagih, sengol (Jawa Barat), beong (Jawa Tengah), baung (Sumatera Selatan), teiken (Sumatera Utara), baon, niken (Kalimantan Barat), patik (Kalimantan Selatan), baung putih (Kalimantan Timur) (Schuster \& Djajadiredja, 1952). Jenis ikan ini hidup di sungai, danau, dan rawa (Gaffar \& Utomo, 1991) dan di waduk. Di sungai ikan baung ditemukan mulai dari muara sampai ke hulu (Gaffar et al., 1988). Penyebaran jenis ikan ini meliputi Sumatera, Kalimantan, dan Jawa (Roberts, 1989). Ikan baung termasuk ikan omnivora (Djajadiredja et al. 1977) sedangkan Tim Studi Inventarisasi Plasma Nutfah Perairan Umum Jambi (1993) mengemukakan bahwa ikan ini termasuk karnivora (pemakan kepiting dan udang). Kottelat et al. (1993) mengemukakan adanya 11 jenis ikan yang tergolong genus Mystus dengan salah satu jenis yang penting adalah $M$. nemurus, yang dapat mencapai ukuran 83 cm (Gaffar, 1998)

Ikan baung tergolong ikan yang digemari masyarakat baik di Jawa, Sumatera maupun Kalimantan. Jenis ikan ini harganya lebih tinggi daripada ikan lokal seperti patin, jenis-jenis Cyprinidae dan jenis ikan budi daya lainnya seperti ikan nila. Ikan ini dikonsumsi dalam bentuk segar maupun diasap. Di Riau ikan asap ini merupakan komoditi ekspor. Daya saing ikan baung relatif tinggi dari ikan lainnya walaupun harganya lebih mahal, karena rasanya yang khas digemari masyarakat (Nasution et al., 1993). Nilai ekonomi ikan baung ratarata mencapai 35-64\%, karena itu mempunyai arti penting bagi kehidupan nelayan. Mengingat pentingnya jenis ikan ini, maka pengelolaan perikanan baung perlu dilakukan agar usaha penangkapannya dapat berkesinambungan

Masalah yang dihadapi ialah adanya penurunan populasi jenis ikan ini di alam karena penangkapan yang terus menerus terutama di Waduk Jatiluhur dan Cirata, sedangkan teknologi budi daya khususnya pembenihannya masih belum ada di masyarakat. Untuk penyebaran dan efisiensi budi daya perlu adanya strain yang produktif

Penelitian ikan baung sudah dilakukan di Daerah Aliran Sungai (DAS) Musi, Sumatera Selatan, yaitu mengenai aspek penangkapan dan ekologinya (Utomo et al., 1993) dan di DAS Batanghari Propinsi Jambi mengenai aspek biologinya (Samuel et al., 1995) serta aspek ekonominya (Nasution et al., 1993), sedangkan pemijahan dengan rangsangan hormon hipofise dan HCG telah dilakukan di Sub Balai Penelitian Perikanan Air Tawar Palembang (Muflikhah et al., 1993). Penelitian pembesaran ikan baung telah dilakukan di kolam dengan kepadatan 1 ekor/m² menunjukkan pertumbuhan yang relatif tinggi yaitu dapat mencapai bobot $112,6 \mathrm{~g}$ dari 45,3g dalam jangka waktu tiga bulan (Muflikhah \& Gaffar, 1992 dan Muflikhah \& Aida, 1996). Di Thailand penelitian ikan baung telah dilakukan terutama pada larva, waktu pemberian pakan, jumlah pakan, dan jenis pakan alami yang sesuai seperti dikemukakan Amornsakun et al. (1996, 1997, 1998a, 1998b, 1998c) dan Amornsakun (1999 \& 2000). Ikan baung diperkirakan mempunyai plasma nutfah yang berbeda, yang memiliki sifat khusus yang menguntungkan, demikian juga ukuran yang dapat dicapai. Oleh karena itu, perlu diketahui strain ikan baung yang mempunyai prospek yang baik untuk dikembangkan sebagai ikan budi daya. Pada penelitian ini telah dicari informasi mengenai sifatsifat yang penting yang diperlukan dalam budi daya, yaitu strain ikan baung yang berasal dari Waduk Cirata, Waduk Jatiluhur, Waduk Wadaslintang, dan Waduk Gajahmungkur (Wonogiri). Pada tahap pertama penelitian yang dilaksanakan adalah karakterisasi dan aspek reproduksi serta pertumbuhan di keramba jaring apung di Waduk Cirata. Pada tahun 1999/2000 dilakukan penelitian tentang evaluasi sifat reproduksi ikan baung ini sebagai kelanjutan dari penelitian tahun-tahun sebelumnya. Tujuan penelitian yang dilakukan adalah mendapatkan sifat reproduksi dari empat strain ikan baung yang dipelihara di keramba jaring apung dalam rangka mendapatkan strain yang produktif serta sifat gelondongan generasi pertamanya.

\section{BAHAN DAN METODE}

\section{Pemeliharaan Induk Empat Strain Ikan Baung}

Empat strain ikan baung (Cirata, Jatiluhur, Wadaslintang, dan Wonogiri) masing-masing dipelihara di dalam keramba jaring apung (ukuran $3 \times 3 \times 2,5 \mathrm{~m}^{3}$ ) dengan kepadatan 18 ekor/jaring. Ikan jantan dan betina dipelihara di dalam keramba yang sama.

Selama pemeliharaan, ikan diberi makanan buatan berupa pelet dengan kadar protein sekitar 30\%, ransum harian $3 \%$ bobot badan, dan frekuensi pemberian tiga kali per hari yaitu pada pukul 9.00, 13.00, dan 17.00 . Pakan ditebarkan di atas saringan halus ukuran $1 \times 1 \mathrm{~m}^{2}$ yang direndam di dasar jaring, sehingga pakan tidak lolos keluar dari jaring

\section{Pengamatan Sifat Reproduksi}

\section{Induk matang gonad}

Pengamatan sifat reproduksi dilakukan terhadap induk-induk yang dipelihara, meliputi perkembangan ovari secara visual (pembengkakan abdomen di atas dan daerah abdomen) serta perkembangan oosit. 
Perkembangan oosit dilihat dengan cara melakukan penyedotan menggunakan kateter berdiameter $2 \mathrm{~mm}$. Kateter dimasukkan ke dalam ovari melalui lubang genital sedalam $5 \mathrm{~cm}$, sedangkan pada jantan kematangan gonad dilihat dari ujung papila yang berwarna kemerah-merahan serta keluarnya cairan kalau dialin

\section{Ukuran dan bobot telur}

Telur hasil penyedotan dengan kateter diawetkan di dalam cairan formalin bufer. Diameter telur diukur dengan menggunakan mikrometer pada mikroskop binokuler. Penimbangan telur yang telah diawet tersebut dilakukan menggunakan timbangan elektronik dengan ketelitian 0,1 mg.

\section{Pemijahan dan indeks ovisomatik (IOS)}

Induk yang matang gonad dipijahkan dengan cara pembuahan buatan. Untuk merangsang ovulasi, induk disuntik hormon gonadotropin komersial dengan merk dagang ovaprim. Penyuntikan dilakukan dua kali dengan interval waktu 6-8 jam. Dosis penyuntikan masing-masing 0,3 dan 0,6 mL/kg bobot induk. Pembuahan buatan dilakukan dengan mengeluarkan telur dengan cara mengalin perut induk kemudian telur ditampung di baskom. Selanjutnya sperma dikeluarkan dari induk jantan dan ditebar di atas telur, kemudian diaduk dengan bulu ayam. Telur dari satu ekor induk dibuahi dengan sperma dari tiga ekor jantan agar meningkatkan keragaman Untuk menghilangkan daya lekat telur dipergunakan cairan tanah lempung dalam keadaan jenuh yang dicampurkan setelah proses fertilisasi, kemudian telur tersebut diangkut dalam kantong plastik yang berisi air dan ditambah oksigen untuk ditetaskan di Bogor. Penetasan dilakukan di dalam corong penetasan dengan aliran air dari bawah.

Bobot telur yang diovulasikan ditentukan berdasarkan perbedaan bobot induk sebelum dan sesudah pengalinan. IOS dihitung berdasarkan rumus (Hardjamulia, 1987):

$$
10 S=\frac{\text { Bobot telur yang diovulasikan }}{\text { Bobot induk sebelum ovulasi }}
$$

\section{Perbandingan Pertumbuhan Benih dari Setiap Strain}

Larva yang dihasilkan, kemudian dipelihara di dalam akuarium sampai mencapai bobot sekitar $5 \mathrm{~g} /$ ekor. Selanjutnya benih dibawa dan dipelihara di Waduk Cirata di dalam waring dengan ukuran mata sekitar $2 \mathrm{~mm}$ sampai mencapai gelondongan dengan bobot sekitar 25 g/ekor. Kemudian gelondongan tersebut dipelihara di keramba jaring apung ukuran $1 \times 1 \times 2,5 \mathrm{~m}^{3}$ dengan kepadatan 50 ekor, kecuali untuk Wadaslintang 18 ekor. Masing-masing strain dipelihara di tiga buah keramba, kecuali untuk strain Wadaslingtang di satu keramba. Rancangan yang dipergunakan adalah rancangan acak lengkap dengan tiga perlakuan dan tiga ulangan. Strain Wadaslintang tidak dimasukkan dalam analisis rancangan tersebut. Pakan diberikan 4\% bobot badan per hari. Pakan yang dipergunakan adalah pakan berbentuk pelet dengan komposisi nutrien seperti tercantum pada Tabel 1. Pengamatan dilakukan setiap 45 hari dan parameter yang dianalisis adalah laju pertumbuhan spesifik (berdasarkan Castell \& Tiews, 1980), sintasan, retensi protein dan lemak (berdasarkan Mokoginta et al., 1995), serta konversi pakan

Sifat fisika dan kimia air yang diamati meliputi suhu air, $\mathrm{pH}, \mathrm{O}_{2}$ terlarut, $\mathrm{CO}_{2}$, alkalinitas, $\mathrm{N}-\mathrm{NH}_{4}$, dan $\mathrm{N}$ $\mathrm{NO}_{2}$.

\section{HASIL DAN BAHASAN}

\section{Jumlah dan ukuran induk}

Jumlah induk keseluruhan dari keempat strain adalah 138 ekor, dan jumlah terbanyak adalah strain Cirata yaitu 79 ekor (Tabel 2). Demikian pula caloncalon induk yang berasal dari Cirata jumlahnya lebih banyak, yaitu 485 ekor (dari keseluruhan 531 ekor)

Tabel 1. Hasil analisis proksimat pakan yang digunakan pada penelitian

Tabel 1. Result of proximate analyses of feed used in the experiment

\begin{tabular}{lcc}
\hline \multicolumn{1}{c}{$\begin{array}{c}\text { Nutrien } \\
\text { Nutrient }\end{array}$} & $\begin{array}{c}\text { Berdasarkan bobot basah } \\
\text { Wet bases (\%) }\end{array}$ & $\begin{array}{c}\text { Berdasarkan bobot ke ring } \\
\text { Dry bases (\%) }\end{array}$ \\
\hline Air (Moisture) & 8.90 & 0.00 \\
Protein (Crude protein) & 27.30 & 29.97 \\
Lemak (Crude fat) & 4.86 & 5.34 \\
Abu (Ash) & 9.61 & 10.55 \\
Serat kasar (Crude fiber) & 2.43 & 2.67 \\
Bahan ekstraks tanpa N & & 51.47 \\
(Nitrogen-free extract) & 46.90 & 100.00 \\
\hline Jumlah (Total) & 100.00 & \\
\hline
\end{tabular}


Tabel 2. Jumlah induk jantan dan betina, jumlah calon induk, serta induk betina yang matang gonad di KJA Table 2. Numbers of male and female brood stocks, and mature female reared in floating net cages

\begin{tabular}{lcccc}
\hline $\begin{array}{l}\text { Strain } \\
\text { Strain }\end{array}$ & $\begin{array}{c}\text { Jml. induk (ekor) } \\
\text { No. brood stock }\end{array}$ & $\begin{array}{c}\text { Jml. jantan (ekor) } \\
\text { No. male }\end{array}$ & $\begin{array}{c}\text { Jml. betina (ekor) } \\
\text { No. female }\end{array}$ & $\begin{array}{c}\text { Ind. betína matang } \\
\text { gonad } \\
\text { No mature female (\%) }\end{array}$ \\
\hline Cirata & $79(485)$ & $39(251)$ & $40(234)$ & $1,435.00$ \\
Jatiluhur & $29(28)$ & $17(15)$ & $12(13)$ & 541.6 \\
Wadaslintang & $16(18)$ & $8(14)$ & $8(4)$ & 112.5 \\
Wonogiri & 14 & 9 & 5 & 120.0 \\
\hline Jumlah (Total) & $138(531)$ & $73(280)$ & $65(251)$ & 21 rataan 27,3 \\
\hline
\end{tabular}

*) angka di dalam kurung menunjukkan jumlah calon induk (figures in brackets denote numbers of future broodstock)

dan di antaranya sudah ada yang mulai matang gonad.

\section{Perkembangan gonad}

Induk-induk ikan baung betina strain Cirata dan Jatiluhur dapat matang gonad selama waktu pengamatan, sedangkan untuk strain Wadaslintang dan Wonogiri induk-induk betina yang matang gonad diperoleh mulai Oktober 1999 (Gambar 1). Jumlah induk yang matang gonad pada bulan Februari 2000, bervariasi antara $12,5 \%-41,6 \%$ dengan rataan $27,3 \%$. Pada pengamatan tahun $1998 / 1999$ semua strain kecuali Wonogiri dapat matang kelamin sepanjang tahun yang dapat dilihat dari telur hasil penyedotan dengan kateter berada pada stadium IV. Dengan demikian pada dasarnya ikan baung dapat dibiakkan sepanjang tahun, tanpa musim. Hal ini menunjukkan bahwa ikan baung dapat beradaptasi cepat terhadap lingkungan budi daya, dan lebih cepat dari ikan perairan umum penting lainnya seperti ikan jelawat. Selain itu induk ikan baung dapat beradaptasi terhadap pakan yang diberikan, yaitu pakan buatan berbentuk pelet, meskipun di alam jenis ikan ini tergolong karnivora. Hal ini menunjukkan bahwa ikan baung mempunyai prospek yang baik sebagai ikan budi daya yang dapat dikembangkan.

\section{Pemijahan dan indeks ovisomatik (IOS)}

Induk yang berhasil dipijahkan dalam kurun waktu 1998-2000 berjumlah 46 ekor ( $92 \%$ ) dari jumlah induk 50 ekor, dengan jumlah induk strain Cirata, Jatiluhur, Wadaslintang, dan Wonogiri masing-masing 18, 11 , 12, dan 5 ekor (Tabel 3). Jumlah induk strain Wonogiri paling sedikit dan kematangan gonadnya lebih lambat. Kisaran bobot induk dari keempat strain yang dipijahkan adalah 185-1.320g dengan kisaran masingmasing strain seperti dikemukakan pada Tabel 4 . Kegagalan ovulasi diperkirakan karena kesalahan

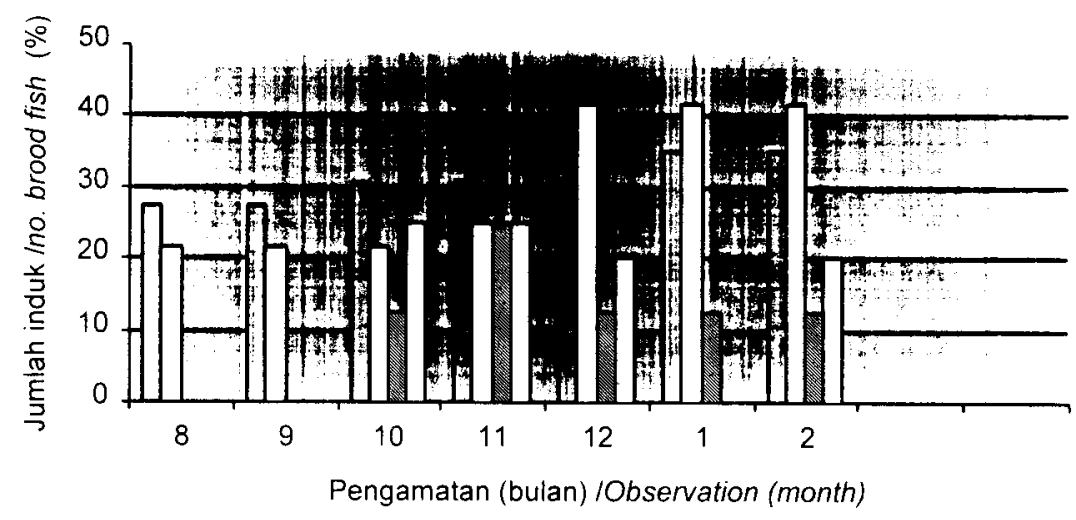

$\square$ Cirata (40) $\square$ Jatiluhur (12) 圈Wd.lintang(8) $\square$ Wonogiri (5)

Gambar 1. Persentase jumlah induk ikan baung (Mystus nemurus) yang matang kelamin pada setiap bulan pengamatan, masing-masing berasal dari Waduk Cirata ( $n=40$ ekor), Jatiluhur ( $n=12$ ekor), Wadaslintang $(n=8)$ dan Wonogiri $(n=5)$

Figure 1. Percentage of mature green catfish (Mystus nemurus) broodstock in each experimental month Cirata ( $n=40)$, Jatiluhur ( $n=12)$, Wadaslintang $(n=8)$ and Wonogiri $(n=5)$ 
Tabel 3. Frekuensi pemijahan dan jumlah induk ikan baung (Mystus nemurus) yang dipijahkan dan
yang berhasil ovulasi

Table 3. Frequency and numbers of green catfish (Mystus nemurus) brood fish induced and their ovulation success

\begin{tabular}{lcccc}
\hline $\begin{array}{c}\text { Strain } \\
\text { Strain }\end{array}$ & $\begin{array}{c}\text { Frekuensi pemijahan } \\
\text { Frequency of } \\
\text { inducement }\end{array}$ & $\begin{array}{c}\text { Jml. induk disuntik } \\
\text { Number of brood fish } \\
\text { injected }\end{array}$ & $\begin{array}{c}\text { Keberhasilan ovulasi Persentase ovulasi (\%) } \\
\text { Number of fish } \\
\text { ovulated }\end{array}$ & $\begin{array}{c}\text { Percentage of } \\
\text { ovulation (\%) }\end{array}$ \\
\hline Cirata & 12 & 19 & 18 & 94.7 \\
Jatiluhur & 9 & 12 & 11 & 91.7 \\
Wadaslintang & 9 & 13 & 12 & 91.3 \\
Wonogiri & 5 & 6 & 5 & 83.8 \\
\hline Jumlah (Total) & 36 & 50 & 46 & 92.0 \\
\hline
\end{tabular}

penentuan kematangan telur, atau jumlah hormon untuk individu ikan tersebut masih kurang sehingga tidak cukup untuk dapat merangsang terjadinya ovulasi.

Periode laten, yaitu kurun waktu antara suntikan kedua (terakhir) dan awal waktu ikan dapat dialin (ovulasi) berkisar antara 6-10 jam. Periode tersebut tidak berbeda dengan periode laten pemijahan ikan patin siam (Pangasius hypophthalmus), dan sama halnya untuk ikan yang tergolong Cyprinidae seperti ikan jelawat (Leptobarbus hoeveni).

Telur ikan baung pada umumnya berwarna coklat dan bersifat lekat jika kontak dengan air. Pada pengalinan biasanya telur kental, sehingga telur tidak memancar dengan mudah. Hal ini menunjukkan bahwa cairan ovarium yang dihasilkan sedikit, dan ini diduga merupakan hal yang baik karena ruang perivitelin tidak cepat mengabsorpsi air pada waktu telur masih ada di dalam ovari, sehingga keberhasilan pembuahan akan lebih tinggi.

Pada awal pengalinan, ikan baung jantan mengeluarkan cairan bening, diikuti cairan berwarna putih, namun encer. Hal ini berbeda dengan ikan patin dan Cyprinidae yaitu pada pengalinan ikan jantan mengeluarkan sperma yang kental berwarna putih. Cairan bening pada pengalinan pertama diduga urin dan sperma keluar pada pengalinan berikutnya. Sperma diduga aktif bergerak di dalam urine tersebut dan dapat membuahi telur. Hal yang penting adalah cairan urin tidak menyebabkan penggumpalan telur, sehingga tidak ada masalah pada waktu pengadukan telur dengan sperma. Pada ikan patin jambal, untuk mencegah pengaktifan spermatozoa oleh urine, sperma diberi larutan garam $\mathrm{NaCl}$ (155-200 mM) (Legendre et al., 2000). Dalam pelaksanaannya sperma disedot dengan alat suntik (syringe) yang mengandung larutan garam tersebut. Derajat fertilisasi ikan baung berkisar antara 22\%-61\%, sedangkan derajat penetasan secara menyeluruh masih rendah berkisar antara 2\%-54\%. Jika pengalinan telur dilakukan bertahap, maka derajat fertilisasi pada pengalinan awal lebih baik daripada telur hasil dari pengalinan berikutnya.

Induk-induk yang telah dipijahkan dengan cara pengalinan dan pembuahan buatan ini dapat matang kembali dan dapat dipijahkan lebih dari satu kali dalam setiap tahunnya. Pada penelitian ini diperoleh seekor induk (bobot $850 \mathrm{~g}$ ) yang dapat dipijahkan tiga kali dalam kurun waktu 151 hari, dengan interval waktu antara pemijahan ke satu dan ke dua 84 hari dan antara pemijahan ke dua dan ke tiga 67 hari. Indeks ovisomatik (IOS) dari induk tersebut pada pemijahan ke satu, ke dua, dan ke tiga masing-masing 9,37 (bobot induk $800 \mathrm{~g}$ ); 7,06 (bobot induk $850 \mathrm{~g}$ ) dan 11,76 (bobot induk $850 \mathrm{~g}$ ). $1 \mathrm{OS}$ dari seluruh strain bervariasi mulai $3,56 \%-13,71 \%$, dengan kisaran masing-masing strain seperti dikemukakan pada Tabel 4.

Tabel 4. Kisaran bobot induk, rataan, dan kisaran indeks ovisomatik (IOS) pada empat strain ikan baung (Mystus nemurus)

Table 4. Range and mean of ovisomatic index (OSI) of four strains of green catfish (Mystus nemurus)

\begin{tabular}{lcccc}
\hline $\begin{array}{c}\text { Strain } \\
\text { Strain }\end{array}$ & $\mathrm{n}$ & $\begin{array}{c}\text { Kisaran bobot induk } \\
\text { Weight range }(\mathrm{g})\end{array}$ & $\begin{array}{c}\text { Rataan IOS } \pm \text { S.D } \\
\text { OSI mean } \pm \text { S.D (\%) }\end{array}$ & $\begin{array}{c}\text { Kisaran IOS } \\
\text { OSI range (\%) }\end{array}$ \\
\hline Cirata & 18 & $256-1.200$ & $8.71 \pm 2.89$ & $4.00-13.71$ \\
Jatiluhur & 11 & $265-800$ & $7.71 \pm 1.96$ & $5.54-10.77$ \\
Wadaslintang & 12 & $185-660$ & $7.62 \pm 2.73$ & $3.56-12.13$ \\
Wonogiri & 5 & $450-1.320$ & $8.75 \pm 2.07$ & $6.67-11.36$ \\
\hline
\end{tabular}




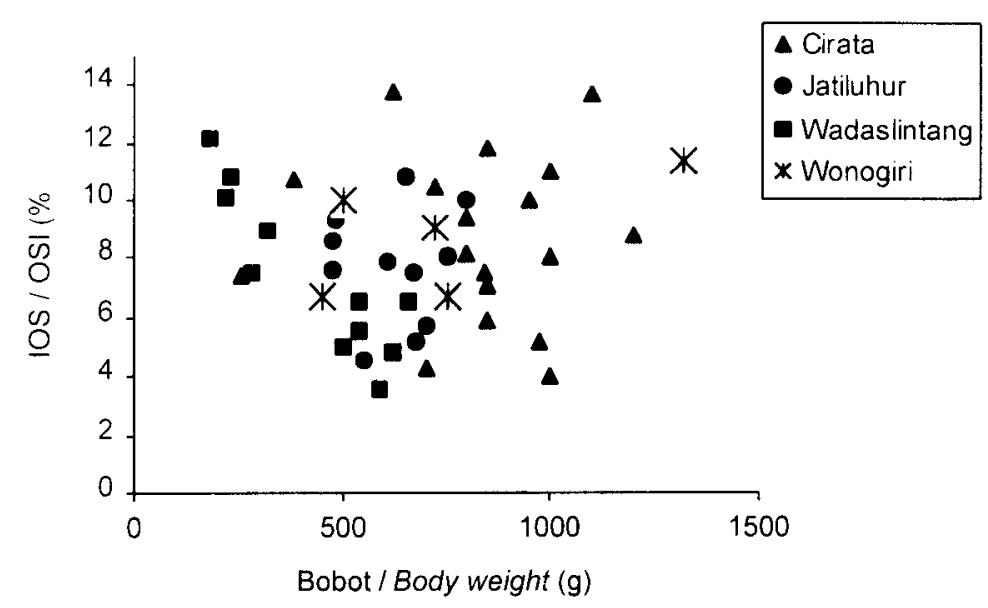

Gambar 2. Distribusi hubungan antara bobot induk dan indeks ovisomatik (IOS) ikan baung (Mystus nemurus) Figure 2. Distribution of OSI for the respective weight of green catfish (Mystus nemurus)

Diagram pencar hubungan bobot induk dan IOS nampak pada Gambar 2. Muflikhah et al. (1993) mendapatkan nilai indeks gonadsomatik (IGS) dari induk yang matang gonad antara $11 \%-16 \%$. Induk tersebut tertangkap pada bulan Desember dan Januari, yaitu pada musim hujan yang diduga merupakan puncak pemijahan di Sungai Musi. Gambar 2 menunjukkan bahwa IOS dari strain Cirata berasal dari induk-induk yang kebanyakan berukuran besar dengan bobot sekitar 1.000-1.200 g, namun IOS-nya bervariasi dari 4,00-13,64. Bobot induk strain Jatiluhur yang mengalami ovulasi mengelompok sekitar 500$800 \mathrm{~g}$, dengan IOS antara 4,54-10,77. Induk yang kecil berukuran $265 \mathrm{~g}$ tidak mengalami ovulasi. Bobot induk strain Wadaslintang pada umumnya kecil, namun kisaran IOS sangat lebar (lihat Tabel 4). Sedangkan bobot induk strain Wonogiri relatif lebih besar dengan IOS yang besar pula, namun jumlah induk yang matang kelamin sedikit (5 ekor).

Hasil analisis regresi bobot ikan dan IOSstrain Cirata tidak menunjukkan pola khusus dengan koefisien determinasi yang paling tinggi $\left(R^{2}=1,80 \%\right)$ diperoleh pada fungsi polinomial. Demikian pula pada strain Jatiluhur, Wadaslintang, dan Wonogiri, koefisien determinasi yang paling tinggi ditemukan pada fungsi polinomial dengan persamaan dan nilai $R^{2}$ sebagai berikut:

$Y_{\text {JI }}=0,00008 X^{2}-0.0926 X+35,254$ dengan $R^{2}=$ $16,86 \%$

$Y_{\text {wdl }}=0,00002 X^{2}-0,0311 X+16,345$ dengan $R^{2}=$ $68,11 \%$

$Y_{\text {wing }}=0,000007 X^{2}-0,009 X+10,843$ dengan $R^{2}=$ $47,64 \%$.

Jadi secara keseluruhan hubungan antara bobot badan dan IOS induk baung mempunyai kecenderungan mengikuti fungsi polinomial.

\section{Fekunditas}

Jumlah telur yang diovulasikan dari keempat strain ikan baung bervariasi antara 10.000 butir (dari bobot induk $256 \mathrm{~g}$ ) sampai 78.950 butir (dari bobot induk $1.320 \mathrm{~g}$ ) untuk setiap ekor induk, atau $18.730-72.60$ butir/kg induk (Tabel 5). Gaffar (1998) mendapatkan fekunditas ikan baung hasil tangkapan di alam sebesar 20.815 butir (bobot induk $327 \mathrm{~g}$ ) dan jumlah telur yang terbanyak 87.118 butir (bobot induk 1.584 g). Alawi et al. (1992) mendapatkan kisaran fekunditas ikan baung berasal dari Sungai Kampar, Riau, 1.395 sampai 160.235 butir (bobot induk $2.752 \mathrm{~g}$ ). Diagram pencar pada Gambar 3 menunjukkan bahwa strain Cirata mempunyai bobot induk yang besar dengan fekunditas yang lebih tinggi dibandingkan dengan strain-strain lainnya.

Strain Wadaslintang mempunyai bobot yang lebih kecil serta fekunditas yang lebih sedikit. Secara umum hubungan antara bobot induk dan fekunditas menunjukkan pola polinomial dengan persamaan dan koefisien determinasi sebagai berikut:

$$
\begin{aligned}
Y_{\text {Cirata }}= & 0,0516 X^{2}-21,814 X+21833 \text { dengan } R^{2}= \\
& 37,20 \% \\
Y_{J l l}= & 0,303 X^{2}-33.29 X+112339 \text { dengan } R^{2}= \\
& 48,19 \% \\
Y_{\text {Wal }}= & 0,2784 X^{2}-277,98 X+99788 \text { dengan } R^{2}= \\
& 51,61 \% \\
Y_{\text {Wng }}= & 0,0735 X^{2}-63,992 X+35679 \text { dengan } R^{2}= \\
& 96,0 \%
\end{aligned}
$$

Fekunditas ikan baung lebih sedikit daripada fekunditas ikan patin siam, namun lebih besar daripada patin jambal. Legendre et al. (2000) mengamati rataan telur patin jambal yang ovulasi adalah $8.500 \pm 4.000$ butir $/ \mathrm{kg}$ induk dengan nilai maksimum yang pernah diperoleh 20.000 butir $/ \mathrm{kg}$ induk 
Tabei 5. Bobot induk, rataan dan kisaran fekunditas (butir/kg induk) dari empat strain ikan baung (Mystus nemurus)

Table 5. Brood fish weight, fecundity (eggs $/ \mathrm{kg}$ fish) mean and range of strain green catfish (Mystus nemurus)

\begin{tabular}{lcccc}
\hline $\begin{array}{c}\text { Strain } \\
\text { Strain }\end{array}$ & $\mathbf{n}$ & $\begin{array}{c}\text { Kisaran bobot induk (g) } \\
\text { Weight range (g) }\end{array}$ & $\begin{array}{c}\text { Rataan fekunditas } \pm \\
\text { SD (butir/kg induk) } \\
\text { Fecundity mean } \\
\text { (egg/kg fish) }\end{array}$ & $\begin{array}{c}\text { Kisaran fekunditas } \\
\text { (butir/kg induk) } \\
\text { Fecundity range } \\
\text { (egg/kg fish) }\end{array}$ \\
\hline Cirata & 18 & $256-1.200$ & $45.860 \pm 15.210$ & $21.050-72.160$ \\
Jatiluhur & 11 & $265-800$ & $35.970 \pm 13.380$ & $23.920-56.680$ \\
Wadaslintang & 12 & $185-660$ & $39.340 \pm 13.890$ & $18.730-64.680$ \\
Wonogiri & 5 & $450-1.320$ & $46.240 \pm 11.070$ & $35.090-59.090$ \\
\hline
\end{tabular}

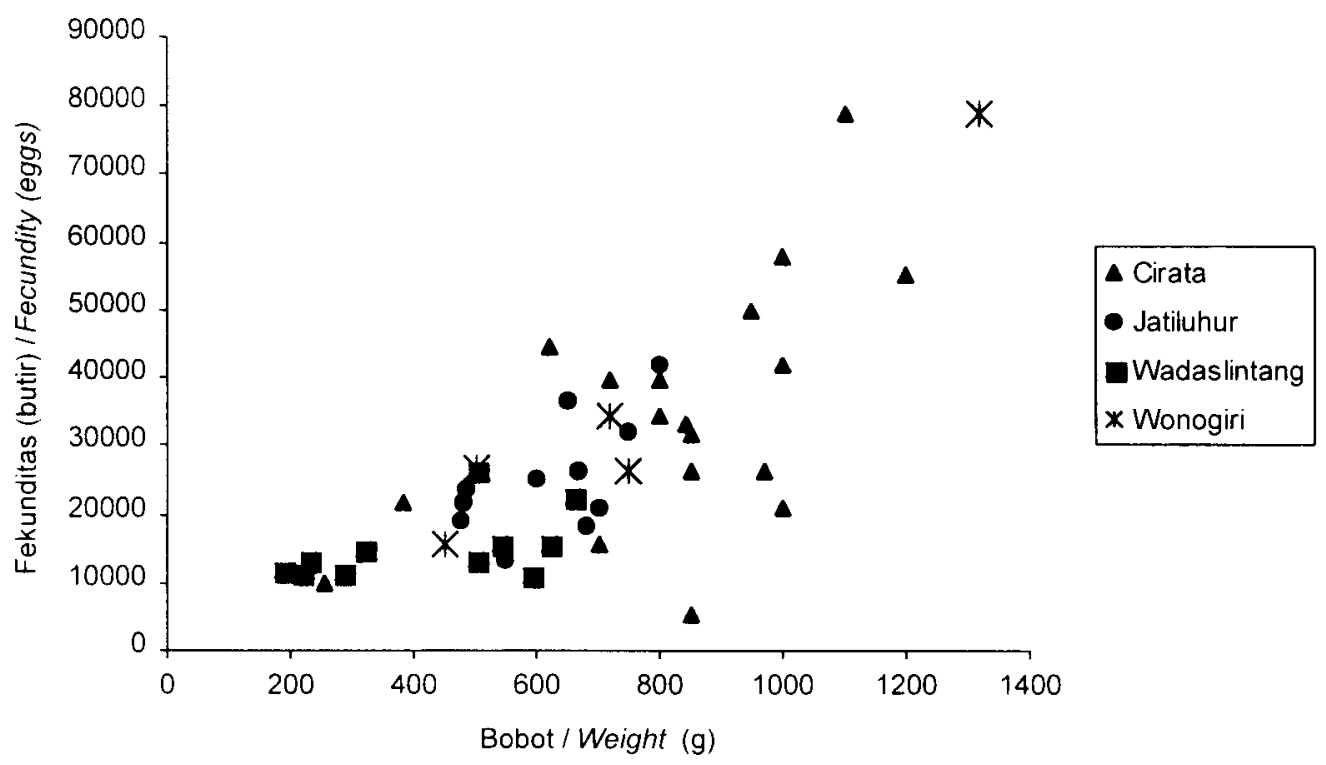

Gambar 3. Distribusi fekunditas untuk masing-masing bobot induk strain ikan baung (Mystus nemurus) Figure 3. Distribution of fecundity for respective brood fish weight of green catfish (Mystus nemurus)

\section{Ukuran dan bobot telur}

Diameter telur ikan baung berkisar antara 1,35$1,63 \mathrm{~mm}$, serta rataan bobot sekitar $1,24-1,46 \mathrm{mg}$ (Tabel6). Bobot telur segar ikan baung mencapai 1,89 $\mathrm{mg} /$ butir. Berdasarkan ukuran tersebut, telur ikan baung tergolong besar dan lebih besar dari telur ikan patin siam. Hal ini sangat menguntungkan karena larva yang dihasilkan berukuran besar yaitu $5.79-6.20 \mathrm{~mm}$ sehingga pakan yang disediakan pada awal mulai makan berukuran besar pula. Biasanya dipergunakan artemia, namun setelah umur 4 hari dapat diberi cacing tubifex.

Tabel 6. Kisaran diameter, rataan bobot dan kisaran bobot terlur strain ikan baung (Mystus nemurus) Table 6. Diameter range, weight mean and weight range of green catfish (Mystus nemurus) eggs

\begin{tabular}{lccc}
\hline $\begin{array}{c}\text { Strain } \\
\text { Strain }\end{array}$ & $\begin{array}{c}\text { Kisaran diameter } \\
\text { Diameter range }(\mathbf{m m})\end{array}$ & $\begin{array}{c}\text { Rataan bobot } \\
\text { Weighrt mean }(\mathbf{m g})\end{array}$ & $\begin{array}{c}\text { Kisaran bobot } \\
\text { Weight range }(\mathbf{m g})\end{array}$ \\
\hline Cirata & $1.37-1.56$ & $1.24 \pm 0.18$ & $1.0-1.6$ \\
Jatiluhur & $1.38-1.63$ & $1.24 \pm 0.36$ & $1.1-1.6$ \\
Wadaslintang & $1.37-1.61$ & $1.46 \pm 0.15$ & $1.2-1.7$ \\
Wonogiri & $1.35-1.63$ & $1.39 \pm 0.21$ & $1.0-1.7$ \\
\hline
\end{tabular}




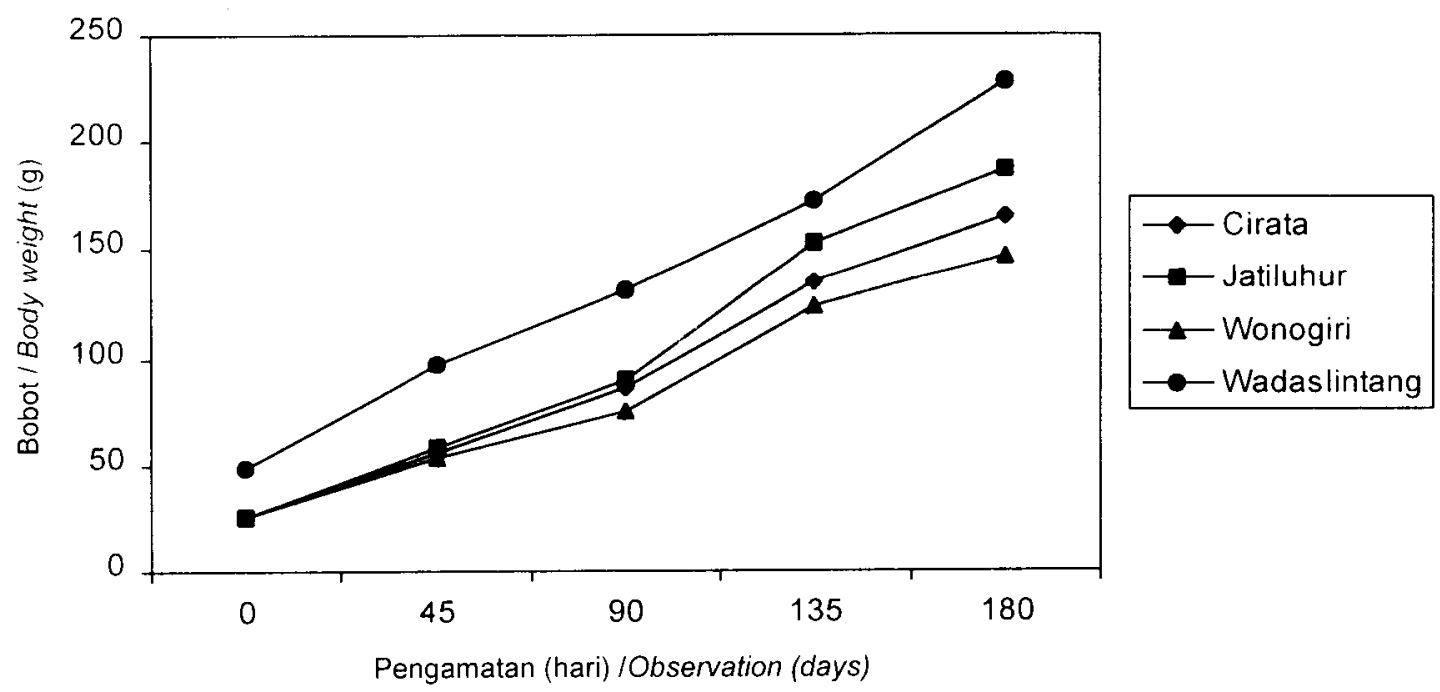

Gambar 4. Grafik bobot gelondongan empat strain ikan baung (Mystus nemurus) pada setiap pengamatan Figure 4. Graph of body weight of four strains green catfish (Mystus nemurus)

\section{Evaluasi sifat gelondongan generasi pertama}

\section{Pertumbuhan}

Ikan baung generasi pertama ukuran gelondongan, pertumbuhannya relatif lambat dengan kisaran bobot antara $146,6-186,8 \mathrm{~g}$, dari bobot awal $25,8 \mathrm{~g}$ pada tiga strain Cirata, Jatiluhur, dan Wonogiri untuk kurun waktu pemeliharaan 180 hari, strain Wadaslintang dengan bobot awal $48,8 \mathrm{~g}$ dapat mencapai $228,4 \mathrm{~g}$ dalam kurun waktu yang sama. Pertumbuhan yang lambat ini antara lain disebabkan oleh pakan yang dipergunakan (kadar protein sekitar 29-30\%). Apabila pakan yang diberikan mengandung kadar protein yang lebih tinggi diduga pertumbuhannya akan lebih baik. Gambar 4 menunjukkan bahwa dari ketiga strain (Cirata, Jatiluhur, dan Wonogiri), strain Jatiluhur pertumbuhannya lebih cepat daripada kedua strain lainnya. Fungsi regresi dari keempat strain tersebut cenderung mempunyai pola polinomial sebagai berikut:

$\begin{aligned} Y_{\text {Cirata }}= & 1,4686 X^{2}+27,045 X-3,832 \text { dengan } R^{2}= \\ & 0,9941\end{aligned}$ $Y_{\text {Jt }}=2,4979 X^{2}+26,65 X-4,78$ dengan $R^{2}=$ 0,9885

$\begin{aligned} Y_{\text {Wngr }}= & 1,145 X^{2}+24,347 X-0,554 \text { dengan } R^{2}= \\ & 0,9858\end{aligned}$

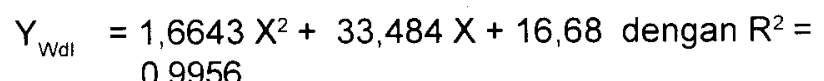

Laju pertumbuhan spesifik strain Jatiluhur lebih cepat $(a=1,29)$ dari ketiga strain lainnya (Tabel 7), sedangkan strain Wadaslintang mempunyai laju pertumbuhan terkecil $(a=0,92)$.

\section{Laju sintasan}

Hal yang menarik dari ikan baung ini adalah ikan tersebut mempunyai daya tahan yang tinggi terhadap lingkungan budi daya di KJA Cirata. Hal ini ditunjukkan oleh sintasan yang relatif tinggi selama pemeliharaan

Tabel 7. Retensi protein dan lemak, serta laju pertumbuhan spesifik strain ikan baung (Mystus nemurus) Table 7. Protein and fat retentions, and specififc growth rate of green catfish (Mystus nemurus)

\begin{tabular}{lccc}
\hline $\begin{array}{c}\text { Strain } \\
\text { Strain }\end{array}$ & $\begin{array}{c}\text { Retensi protein } \\
\text { Protein retention } \\
(\boldsymbol{\%})\end{array}$ & $\begin{array}{c}\text { Retensi lemak } \\
\text { Fat retention } \\
(\%)\end{array}$ & $\begin{array}{c}\text { Laju pertumbuhan spesifik } \\
\text { Specific growth rate }\end{array}$ \\
\hline Cirata & 19.16 & 29.92 & 1.21 \\
Jatiluhur & 20.70 & 30.74 & 1.29 \\
Wonogiri & 16.75 & 31.82 & 1.14 \\
Wadaslintang & $\mathrm{td})$ & $\mathrm{td})$ & 0.92 \\
\hline
\end{tabular}

Td) tidak ada data, sampel tidak diambil (no data available) 


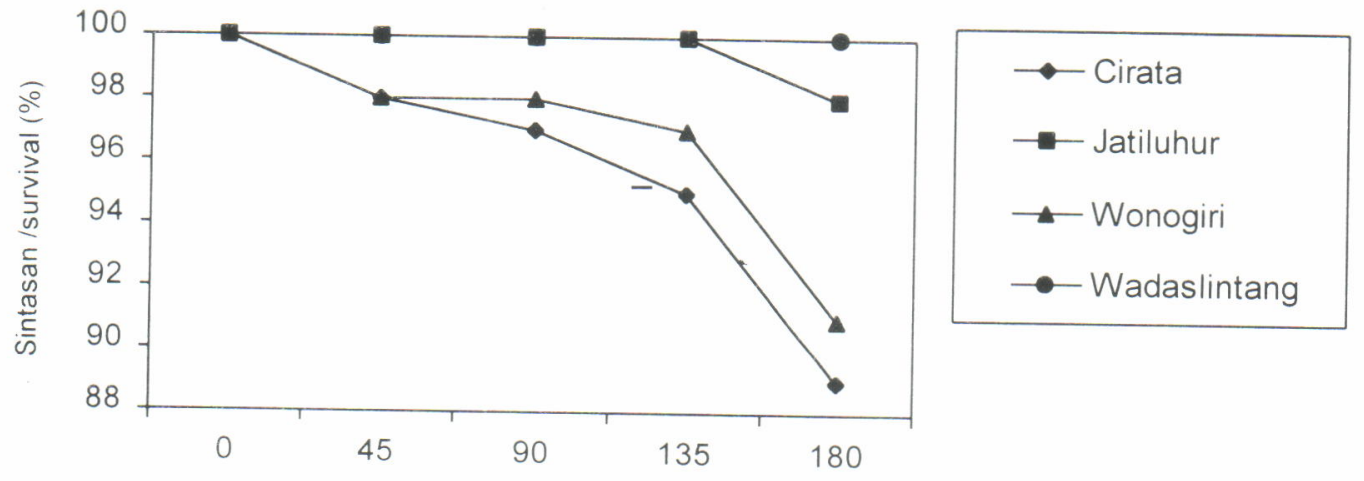

Pengamatan (hari)/ observation (days)

Gambar 5. Laju sintasan gelondongan ikan baung (Mystus nemurus) yang dipelihara selama 180 hari di keramba jaring apung

Figure 5. Survival rate of green catfish (Mystus nemurus) reared in floating net cages

180 hari dengan kisarannya antara 89\%-100 \% (Gambar 5). Kematian diduga sebagai akibat dari penanganan pada waktu penimbangan, meskipun periode pengamatan diperlebar menjadi 45 hari. Parasit tidak nampak pada tubuh ikan, demikian pula tidak ada luka atau borok yang disebabkan penyakit. Kematian mungkin pula karena kanibalisme, khususnya pada ikan-ikan yang lemah akibat penanganan.

\section{Retensi Protein dan Lemak}

Informasi mengenai retensi protein dan retensi lemak akan memberikan gambaran tentang kemampuan ikan baung ini untuk menyimpan protein dan lemak di dalam tubuhnya. Gelondongan strain Jatiluhur menunjukkan kemampuan penyimpanan protein yang lebih tinggi daripada strain Wonogiri, sedangkan terhadap strain Cirata tidak berbeda (Tabel 7). Retensi lemak untuk ketiga strain tidak menunjukkan perbeda- an $(P<0.05)$. Gelondongan ikan baung nampaknya mempunyai kemampuan untuk menyimpan lemak lebih tinggi daripada protein.

Hal yang menarik adalah dari hasil analisis proksimat pada daging gelondongan cenderung berkadar protein lebih tinggi, namun kadar lemak lebih rendah (Tabel 8).

\section{Konversi Pakan}

Nilai konversi pakan bergantung pada lama pemeliharaan. Pada periode pemeliharaan 135 hari nilai konversi berkisar antara $2,41-2,86$, yaitu untuk strain Cirata, Jatiluhur, dan Wadaslintang; sedangkan untuk pemeliharaan 180 hari berkisar antara 3,30-4,00. Konversi pakan strain Jatiluhur adalah yang terbaik $(2,41)$, sedangkan strain Wonogiri dengan bobot awal yang lebih besar mempunyai nilai konversi terjelek. bahkan untuk periode pemeliharaan 135 hari lebih jelek

Tabel 8. Kadar air, protein dan lemak gelondongan ikan baung (Mystus nemurus) pada awal (ditulis miring)

Table 8. Moisture, protein and fat content of green catfish (Mystus nemurus) fingerling meat on the beginning (in italics) and the end of the experiment

\begin{tabular}{|c|c|c|c|c|c|c|}
\hline \multirow{2}{*}{$\begin{array}{l}\text { Strain } \\
\text { Strain }\end{array}$} & \multirow{2}{*}{$\begin{array}{c}\text { Rataan bobot ikan } \\
\text { Average Body } \\
\text { Weight (g) }\end{array}$} & \multirow{2}{*}{$\begin{array}{l}\text { Kadar air } \\
\text { Moisture } \\
\text { content (\%) }\end{array}$} & \multicolumn{2}{|c|}{$\begin{array}{l}\text { Kadar protein } \\
\text { Protein content }\end{array}$} & \multicolumn{2}{|c|}{$\begin{array}{l}\text { Kadar lemak } \\
\text { Fat content }\end{array}$} \\
\hline & & & $\begin{array}{c}\text { B. Kering } \\
\text { Wet bases } \\
(\%)\end{array}$ & $\begin{array}{c}\text { B. Kering } \\
\text { Wet bases } \\
(\%)\end{array}$ & $\begin{array}{c}\text { B. Kering } \\
\text { Wet bases } \\
(\%)\end{array}$ & $\begin{array}{c}\text { B. Kering } \\
\text { Wet bases } \\
(\%)\end{array}$ \\
\hline Cirata & $\begin{array}{c}25.8 \\
134.7\end{array}$ & $\begin{array}{l}76.81 \\
73.14\end{array}$ & $\begin{array}{l}58.54 \\
63.90\end{array}$ & $\begin{array}{l}13.63 \\
17.16\end{array}$ & $\begin{array}{l}12.95 \\
17.31\end{array}$ & $\begin{array}{l}3.02 \\
4.65\end{array}$ \\
\hline Jatiluhur & $\begin{array}{c}25.8 \\
152.7\end{array}$ & $\begin{array}{l}74.58 \\
72.68\end{array}$ & $\begin{array}{l}58.54 \\
64.08\end{array}$ & $\begin{array}{l}14.88 \\
17.51\end{array}$ & $\begin{array}{l}10.53 \\
16.08\end{array}$ & $\begin{array}{l}2.68 \\
4.39\end{array}$ \\
\hline Wonogiri & $\begin{array}{r}25.8 \\
124.0\end{array}$ & $\begin{array}{l}75.07 \\
73.53\end{array}$ & $\begin{array}{l}51.99 \\
61.30\end{array}$ & $\begin{array}{l}12.96 \\
16.23\end{array}$ & $\begin{array}{l}15.05 \\
20.07\end{array}$ & $\begin{array}{l}3.45 \\
5.31\end{array}$ \\
\hline Wadaslintang & 48.8 & 72.28 & 61.82 & 17.14 & 18.96 & 5.26 \\
\hline
\end{tabular}


Tabel 9. Pertambahan bobot ikan, jumlah pakan dan konversi pakan gelondongan ikan baung (Mystus nemurus) pada periode pemeliharaan 135 dan 180 hari

Table 9. Weight gain, feed weight, and feed conversion ratio of green catfish (Mystus nemurus) on 135 and 180 days rearing periods

\begin{tabular}{ccccc}
\hline $\begin{array}{c}\text { Strain } \\
\text { Strain }\end{array}$ & $\begin{array}{c}\text { Periode } \\
\text { pemeliharaan (hari) } \\
\text { Rearing period (days) }\end{array}$ & $\begin{array}{c}\text { Pertamb. bobot } \\
\text { Weight gain (g) }\end{array}$ & $\begin{array}{c}\text { Jumlah pakan } \\
\text { Feed weight (g) }\end{array}$ & $\begin{array}{c}\text { Konversi pakan } \\
\text { Feed conversion ratio }\end{array}$ \\
\hline Cirata & 135 & 5.132 & 14.493 & 2.82 \\
\multirow{2}{*}{ Jatiluhur } & 180 & 6.096 & 2.297 & 3.76 \\
& 135 & 6.447 & 15.530 & 2.41 \\
Wadaslintang & 180 & 7.803 & 25.723 & 3.30 \\
\multirow{2}{*}{ Wonogiri } & 135 & 4.758 & 13.610 & 2.86 \\
& 180 & 5.402 & 21.603 & 4.00 \\
& 135 & 2.220 & 8.945 & 4.03 \\
& 180 & 2.775 & 15.105 & 5.49 \\
\hline
\end{tabular}

daripada konversi untuk periode pemeliharaan 180 hari pada ketiga strain lainnya.

Pertumbuhan, nilai konversi pakan yang diperoleh relatif kurang baik dibandingkan dengan yang diperoleh pada komoditas lainnya. Hal ini diduga karena kadar nutrien pakan terutama kadar protein pakan yang diberikan tidak memenuhi kebutuhan untuk pertumbuhan optimal ikan baung. Khan et al. (1994) menyatakan bahwa pertumbuhan dan konversi pakan yang terbaik diperoleh apabila ikan baung diberi pakan dengan kadar protein $42 \%$.

\section{Sifat Fisika Kimia Air}

Pada waktu pengambilan contoh dan pengamatan kualitas air, udara cerah dan tidak ada angin. Suhu permukaan air $\left(30^{\circ} \mathrm{C}\right)$ relatif tinggi pada waktu pagi (pukul 9.00). Hal ini akan berpengaruh terhadap peningkatan aktivitas metabolisme ikan. Tingkat keasaman air ( $\mathrm{pH}=7,5)$ sangat baik untuk kehidupan ikan, sehingga diperkirakan tidak ada masalah. Kadar oksigen yang diamati antara 3,2-5,4 mg/L tergolong agak rendah, sebaiknya di atas $5 \mathrm{mg} / \mathrm{L}$. Kadar oksigen yang rendah dan dipergunakan pula untuk respirasi dan proses perombakan bahan organik, dapat berpengaruh terhadap nafsu makan yang berkurang sehingga dapat berpengaruh terhadap pertumbuhan Kisaran jkdar $\mathrm{CO}_{2}$ antara 9,57-13,39 $\mathrm{mg} / \mathrm{L}$ masih tergolong normal dan tidak ada masalah. Hal yang penting lainnya adalah konsentrasi amonia $(0,12-0,42$ $\mathrm{mg} / \mathrm{L}$ ) untuk gelondongan relatif membahayakan, karena ikan dapat mengalami stres untuk jangka

Tabel 10. Sifat fisika kimia air di keramba jaring apung di tempat penelitian induk dan gelondongan ikan baung (Mystus nemurus) pada pengamatan pukul 9.00 pagi

Table 10. Physical and chemical water properties in green catfish (Mystus nemurus) broodstock and fingerling loating net cages at 9.00 hours

\begin{tabular}{|c|c|c|c|c|c|c|c|}
\hline $\begin{array}{l}\text { Lokasi contoh air } \\
\text { Sampling site }\end{array}$ & $\begin{array}{l}\text { Suhu } \\
\text { Temp. } \\
\left({ }^{\circ} \mathrm{C}\right)\end{array}$ & $\mathrm{pH}$ & $\begin{array}{c}\mathrm{O}_{2} \\
(\mathrm{mg} / \mathrm{L})\end{array}$ & $\begin{array}{c}\mathrm{CO}_{2} \\
(\mathrm{mg} / \mathrm{L})\end{array}$ & $\begin{array}{c}\text { Alkalinitas } \\
\text { Alkalinity } \\
\mathrm{mg} / \mathrm{L}\end{array}$ & $\begin{array}{l}\mathrm{N}-\mathrm{NH}_{4} \\
(\mathrm{Mg} / \mathrm{L})\end{array}$ & $\begin{array}{l}\mathrm{N}-\mathrm{NO}_{2} \\
(\mathrm{Mg} / \mathrm{L})\end{array}$ \\
\hline \multicolumn{8}{|c|}{ KJA induk (Broodstock cages) } \\
\hline Cirata & 30.0 & 7.5 & 5.20 & 11.79 & 71.18 & 0.085 & 0.357 \\
\hline Jatiluhur & 30.0 & 7.5 & 4.80 & 12.79 & 71.18 & 0.091 & 0.318 \\
\hline Wd.lintang & 30.0 & 7.5 & 4.80 & 13.79 & 71.18 & 0.081 & 0.281 \\
\hline Wonogiri & 30.0 & 7.5 & 4.80 & 11.79 & 71.18 & 0.085 & 0.272 \\
\hline \multicolumn{8}{|c|}{ KJA gelond. (Fingerling cages) } \\
\hline Cirata & 29.5 & 7.5 & 3.80 & 13.79 & 71.18 & 0.142 & 0.367 \\
\hline Jatiluhur & 29.5 & 7.5 & 4.00 & 12.79 & 71.18 & 0.121 & 0.300 \\
\hline Wd. lintang & 30.0 & 7.5 & 4.80 & 9.59 & 71.18 & 0.117 & 0.318 \\
\hline Wonogiri & 30.0 & 7.5 & 3.20 & 13.79 & 71.18 & 0.117 & 0.290 \\
\hline
\end{tabular}


waktu yang panjang ditambah lagi dengan kadar nitrit yang relatif tinggi yaitu sekitar $0,3 \mathrm{mg} / \mathrm{L}$. Schmittou (1991) berpendapat bahwa jika kandungan kedua senyawa tersebut dalam perairan melebihi 0,1 mg/L dapat menyebabkan stres pada ikan yang ada dalam perairan tersebut.

\section{KESIMPULAN}

Kesimpulan yang dapat diambil dari penelitian ini adalah sebagai berikut:

1. Ikan baung dapat matang kelamin di keramba jaring apung (KJA) dengan pemberian pakan buatan berupa pelet dengan kandungan protein sekitar $30 \%$

2. Pada pengamatan mulai Agustus 1999 sampai dengan Februari 2000, ikan baung strain Cirata dan Jatiluhur dapat matang kelamin, sedangkan strain Wadaslintang dan Wonogiri yang matang gonad ditemukan mulai bulan Oktober 1999

3. Indeks ovisomatik (IOS) mempunyai kisaran yang cukup besar, yaitu antara 3,56-13,71 dengan kecenderungan strain Cirata dan Wonogiri mempunyai IOS yang lebih besar daripada kedua strain lainnya

4. Fekunditas atau telur yang diovulasikan, mempunyai kisaran yang besar pula, yaitu antara 18.730 sampai dengan 72.160 butir/kg induk, dengan kecenderungan strain Ciarata dan Wonogiri mempunyai fekunditas yang lebih besar dari kedua strain lainnya

5. Pengamatan pertumbuhan, retensi protein, dan lemak pada ikan baung ukuran gelondongan, strain Jatiluhur menunjukkan hasil terbaik dibandingkan dengan ketiga strain lainnya

\section{DAFTAR PUSTAKA}

Alawi, H. M. Ahmad, Rusliadi, dan Pardiman. 1992. Some biological aspects of micrones catfish (Macrones nemurus C.V.) from Kampar River. Terubuk XVII, $52: 32-47$.

Amornsakun, T. 1999. Some aspects in early life stages of larval red-tail catfish. Mystus wyckioides. Songklanakarin. J. Sci. Technol. 21 (4):401-406.

Amornsakun, T. 2000. Influences of initial delay of feeding on growth and survival of red-tail catfish, Mystus wyckioides. Songklanakarin. J. Sci.Technol. 22(1): 51-55.

Amornsakun, T., Chiayvareesajja, S., and Hassan, A. 1996. Starvation and initial delay of feeding on larval green catfish, Mystus nemurus (Cuv. \& Val.). Songklanakarin. J. Sci.Technol. 18 (4): 443-446.

Amornsakun, T., Chiayvareesajja, S., Hassan, A., Ambak, A., and Jee, A. 1997. Yolk absorption and start feeding of larval green catfish, Mystus nemurus (Cuv.\&Val.). Songklanakarin. J. Sci. Technol. 19(1): $117-122$
Amornsakun, T., Hassan, A., Ambak, A., and Chiayvareesajja, S. 1998a. The culture of green catfish. Mystus nemurus (Cuv.\&Val.) I: Feed and feeding scheme of larvae and juveniles. Songklanakarin. $J$. Sci. Technol. 20(3): 373-378.

Amornsakun, T., A. Hassan, A. Ambak, and S. Chiayvareesajja. 1998b. The culture of green catfish, Mystus nemurus (Cuv.\&Val.) II: Gastric emptying times and feed requirements of larvae feed with Moina Songklanakarin. J. Sci. Technol. 20(3): 379-384.

Amornsakun,T., Hassan, A., Ambak, A., and Chiayvareesajja, S. 1998c. Feeding periodicity under natula light condition of larval green catfish, Mystus nemurus (Cuv.\&Val.). Songklanakarin. J. Sci. Technol. 20(2): 219-223

Castell, J.D. and Tiews, K. 1980. Reports of the EIFAC, IUNS and ICES Working Group on Standardization of Methodology in Fish Nutrition Research. EIFAC Technical Paper No. 36. FAO Rome. 24 pp

Djajadiredja, R, Hatimah, S., dan Arifin, Z. 1977. Buku Pedoman Pengenalan Smber Perikanan Darat Bagian I (Jenis-jenis Ikan Ekonomi Penting). Direktorat Jenderal Perikanan. Jakarta. 96 pp.

Gaffar, A.K., Rifai, S.A., Utomo, A.D., dan Adjie, S. 1988 Karakteristik limnologi Sungai Komering. Bull. Penel. Perikanan Darat 7(2): 66-67

Gaffar, A. K. dan A. D. Utomo. 1991. Sumberdaya perikanan S. Komering Bull. Penel. Perikanan Darat 10(3):1-6.

Gaffar, A.K. dan Muflikhah, N. 1992. Pemijahan buatan dan pemeliharaan larva ikan baung. Pros. Seminar Hasil Penelitian Perikanan Air Tawar 1991/1992. Balitkanwar, Bogor. p. 254-257

Gaffar, A.K., Muflikhah, N., dan Josmaniar. 1993. Domestikasi ikan baung (Macrones nemurus C.V.). Pros. Puslitbangkan No. 26/1992. p. 160-165.

Gaffar, A.K. 1998. Ikan baung (Mystus nemurus) si kumis dari perairan tawar. Warta Penelitian Perikanan Indonesia. IV(1): 16-18.

Hardjamulia, A., Suhenda, N., dan Wahyudi, E. 1995. Perkembangan oosit dan ovari ikan semah (Tor douronensis) di Sungai Selabung, Danau Ranau, Sumatera Selatan. Jurnal Penelitian Perikanan Indonesia I(3): 36-46

Hardjamulia, A. 1987. Beberapa Aspek Pengaruh Penundaan dan Frekuensi Pemijahan terhadap Potensi Produksi Ikan Mas (Cyprinus carpio). Fakultas Pasca Sarjana. IPB. Disertasi. $121 \mathrm{p}$

Khan, M.S., Ang, K.J., and Das, N.N. 1994. Amino acid nutrition in formulating the diets for tropical freshwater catfish, Mystus nemurus C \& V. in Malaysia. In Chou et al. (Eds.). Proc. Third Asian Fisheries Forum, The Asian Fisheries Society Manila, Philippines. p. 678680.

Kottelat, M, Whitten, A.J., Kartikasari, S.N., and Wirjoatmodjo, S. 1993. Freshwater fishes of Western Indonesia and Sulawesi. Periplus. Ed. Ltd. 293 $\mathrm{pp}$.

Legendre, M., Pouyaud, L., Slembrouck, J., Gustiano, R., Kristanto, A.H., Subagja, J., Komarudin, O., Sudarto, 
and Maskur. 2000. Pangasius jambal: A new candidate species for fish culture in Indonesia. Indonesian Agricultural Research \& Development Journal 22 (1). $8 \mathrm{pp}$.

Mokoginta, I., Suprayudi, M.A. dan Setiawan, M. 1995 Kebutuhan optimum protein dan energi pakan benih ikan gurame (Osphronemus gouramy Lac.). Pusat Penelitian dan Pengembangan Perikanan Jakarta Jurnal Penelitian Perikanan Indonesia I(3):82-94.

Muflikhah, N dan Gaffar, A.K. 1992. Pengaruh perbedaan padat tebar terhadap pertumbuhan ikan baung (Mystus nemurus) di kolam stagnan. Bull. Penel. Perikanan Darat 11(2): 129-133.

Muflikhah, N., Yosmaniar dan Jahri, M 1993. Penelitian tehnik kawin rangsang dan budidaya ikan baung (Mystus nemurus C.V.). Rakernis Balitkanwar Sukamandi 24-26 Mei 1993. 10 pp.

Muflikhah, N dan Aida, S.N. 1996. Pengaruh frekwensi pemberian pakan yang berbeda terhadap pertumbuhan dan kelangsungan hidup benih ikan baung (Mystus nemurus). Prosiding Lolitkanwar No. 2/1996. p. 108-111

Nasution, Z., Utomo, A.D., Prasetyo, D., dan Yusuf, S. 1993. Kajian ekonomi pada sumberdaya perikanan baung di DAS Batanghari, Propinsi Jambi. Rakernis Balitkanwar Sukamandi 24-26 Mei 1993. 11 pp

Roberts, T.R. 1989. The freshwater fishes of Western Borneo (Kalimantan Barat, Indonesia). California Academy of Science. $210 \mathrm{pp}$.

Samuel, Adjie, S., dan Akrimi. 1995. Beberapa aspek biologi ikan baung (Mystus nemurus) di Daerah Aliran Sungai Batanghari, Propinsi Jambi. Oseanologi dan Limnologi di Indonesia 28: 1-13.

Schmittou, H.R. 1991. Cage Culture: A Method of Fish Production in Indonesia. FRDP. Central Research Institute for Fisheries, Jakarta, Indonesia. 114 pp.

Schuster, W.H. and Djajadiredja. 1952. Local Common Names of Indonesian Fishes. W. Van. Hoeve Bandung, 's-Gravenhage. $276 \mathrm{pp}$.

Tim Studi Inventarisasi Plasma Nutfah Perairan Umum Jambi. 1993. Studi Identifikasi/lnventarisasi Plasma Nutfah Perikanan Perairan Umum Propinsi Jambi. Dinas Perikanan Propinsi Daerah Tingkat I Jambi. $119 \mathrm{pp}$.

Utomo, A. D. Z. Nasution, dan A. Sudrajat. 1993. Aspek penangkapan dan ekologi perikanan baung di DAS Musi Sumatera Selatan. Rakernis Balitkanwar Sukamandi 24-26 Mei 1993. 14 pp. 